\title{
Cellular immunity in children with successful immunoprophylactic treatment for mother-to-child transmission of hepatitis B virus
}

\author{
Haruki Komatsu*1,2, Ayano Inui1, Tsuyoshi Sogo1, Eitaro Hiejima1', Akihiko Tateno², Paul Klenerman³ and \\ Tomoo Fujisawa'
}

\begin{abstract}
Background: The administration of hepatitis B immunoglobulin followed by hepatitis B vaccine can result in a protective efficacy of almost $90 \%$ in mother-to-child transmission of hepatitis B virus (HBV). However, little is known about immunity against HBV infection in children after immunoprophylactic treatment. We tried to assess the association between T-cell responses and viremia in children after successful prophylactic treatment.

Methods: Thirteen children and their 8 HBV carrier mothers (8 families), who were positive for human leukocyte antigen (HLA)-A24, were enrolled in this study. All of the 13 children received immunoprophylactic treatment and became negative for hepatitis B surface antigen (HBsAg) after birth. HBV-specific cytotoxic T lymphocyte (CTL) responses were evaluated using IFNY - enzyme-linked immunosorbent spot (ELISPOT) and major histocompatibility complex class I peptide pentamer assays. Serum HBV DNA was measured by real-time PCR.

Results: Significant HBV-specific T-cell responses were detected in 2 (15\%) of the 13 children by ELISPOT. However, the frequency of HLA-A24-HBV-specific CTLs was very low in both HBV carrier mothers and children using pentamers. Of the 13 children, 4 (31\%) were positive for serum HBV DNA. However, the levels of serum HBV DNA were 100 copies/ml or less. One of the 2 children in whom significant HBV-specific CTL responses were detectable was positive for serum HBV DNA.

Conclusions: HBV core and polymerase-specific T-cell responses were detected and a low-dose viremia was observed in children after successful immunoprophylaxis treatment. Although the presence of viremia was not related to HBVspecific T-cell responses, CTLs might play a role in the control of HBV infection in children born to HBsAg-positive mothers after immunoprophylactic treatment.
\end{abstract}

\section{Background}

Worldwide, hepatitis B virus (HBV) is a common cause of liver disease. An estimated 350 million persons are chronically infected with HBV, and these individuals have a $15-25 \%$ risk of dying from HBV-related disease, including liver cirrhosis, hepatic decompensation, and hepatocellular carcinoma $[1,2]$. HBV is 100 times more infectious than human immunodeficiency virus and is transmitted by percutaneous or mucosal exposure to infected blood or other body fluids. Perinatal transmis-

* Correspondence: haruki-komatsu@chive.ocn.ne.jp

1 Department of Pediatrics, Yokohama Eastern Hospital, 3-6-1 Shimosueyoshi Tsurumi Yokohama, Kanagawa 230-0012, Japan

Full list of author information is available at the end of the article sion, household contact, sexual contact, blood transfusion, and unsterilized injection are known as common routes of HBV transmission. The risk of mother-to-child transmission is $5-20 \%$ if the mother is positive for hepatitis B surface antigen (HBsAg) alone, but $90 \%$ if the mother is positive for hepatitis B e antigen ( $\mathrm{HBeAg}$ ) [3]. To prevent mother-to-child transmission at or around birth, hepatitis B immunoglobulin (HBIG) is administrated for newborns born to HBsAg-positive mothers within $12 \mathrm{hr}$ after birth combined with a three-dose series hepatitis $B$ vaccine in many countries, including Japan $[4,5]$. HBIG has high levels of antibodies to HBsAg (antiHBs), which are neutralizing antibodies against HBV. HBIG is immediately effective and protective for a few 
months after birth. However, the levels of anti-HBs decrease over time. Therefore, active vaccination is required to sustain sufficient levels of anti-HBs to protect young infants from HBV infection. This combination strategy can show a protective efficacy of almost $90 \%$ and results in fewer than $5 \%$ of infants becoming HBV carriers [6-8].

Little is known about immunity from HBV infection in children after successful immunoprophylactic treatment, resulting in several questions about immunity post-vaccination. For example, it remains controversial whether the appearance of anti-HBs in children born to HBsAg-positive mothers implies complete protection from $\mathrm{HBV}$ infection after birth. Previous studies showed that serum HBV DNA was detected by polymerase chain reaction (PCR) in children born to HBsAg-positive mothers even after anti-HBs were induced by hepatitis $B$ vaccine $[9,10]$. These findings suggested that children born to HBsAgpositive mothers have a risk of becoming HBV carriers even if immunoprophylactic treatment was successfully administered. Although the levels of serum HBV DNA are low in these anti-HBs-positive children after immunoprophylactic treatment, it is nevertheless a concern that reactivation of $\mathrm{HBV}$ replication could occur if these children receive immunosuppressive therapy.

In addition, the responses of $\mathrm{HBV}$-specific cytotoxic $\mathrm{T}$ lymphocytes (CTLs) have never been evaluated in children after prophylactic treatment. HBV-specific CTLs play a major role in the control of $\mathrm{HBV}$ infection [11]. Because hepatitis $B$ vaccine is derived from surface protein, theoretically Th2 cytokines associated with helper $\mathrm{T}$ lymphocytes are produced in response to vaccination [12]. To stimulate major histocompatibility complex (MHC) Class I restricted CD8+ CTLs, endogenous peptides processing and presentation is required. Although HBs peptide-specific CTLs can be induced by hepatitis $B$ vaccine, whether CTL responses to other peptides derived from core and polymerase regions are primed remains unclear. There is, therefore, a possibility that HBV-core protein or -polymerase protein-specific CTLs would be detectable in children born to HBsAg-positive mothers if these children were exposed to HBV transiently or persistently at or after birth.

The aim of this study was to clarify the association between HBV-specific CTL responses and HBV viremia in children born to HBsAg-positive mothers after successful immunoprophylactic treatment. HBV-specific CTL responses were evaluated using enzyme-linked immunosorbent spot (ELISPOT) and MHC Class I peptide pentamer assays. Because human leukocyte antigen (HLA)-A24 is the most common HLA type in Japan, HBV-specific HLA-A24-restricted CTL epitopes were used for assays. Serum HBV DNA was measured by realtime PCR, which is a powerful tool for the detection of
HBV DNA. Our data suggest that low-level viremia may occur and that this may be associated with priming of CTL responses even after apparently successful immunoprophylaxis.

\section{Methods \\ Patients}

This cross sectional study was approved by the Ethics Committee. Informed consent for study participation was obtained from the patients or their parents. Between 2002 and 2007, fifty-one women [HBeAg positive, $\mathrm{n}=18$; antibodies to hepatitis $\mathrm{B}$ e antigen (anti-HBe) positive, $\mathrm{n}$ = 33] [age range: $18-51$ years; mean age \pm SD: $34.4 \pm 7.7$ years] with chronic hepatitis B were followed in our department (Figure 1). All of the women were positive for HBsAg and negative for anti-HBs. None of them had received any anti-viral treatment before, during, or after delivery. Of the 51 women with chronic hepatitis B infection, 40 were mothers (HBeAg positive, $n=15$; anti-HBe positive, $\mathrm{n}=25$ ). HLA typing using flow cytometry was performed in the 40 mothers, of whom 28 (HBeAg positive, $\mathrm{n}=11$; anti-HBe positive, $\mathrm{n}=17$ ) were positive for HLA-A24. Of the 28 HLA-A24-positive mothers, 25 (HBeAg positive, $\mathrm{n}=10$; anti-HBe positive, $\mathrm{n}=15$ ) were followed with their children in our department. The 25 mothers had 33 children (male/female $=16 / 17$; age range: 0 - 22 years; mean age \pm SD: $5.3 \pm 4.4$ years). Of the 33 children, 7 children were positive for HBsAg and the remaining 26 children were negative for $\mathrm{HBsAg}$. Of the 33 children, 16 were positive for HLA-A24. Of the 16 children, 3 were chronically infected with HBV. These 16 HLA-A24-positive children were born from 11 of the 25 HLA-A24-positive mothers. Therefore, both mothers and children were positive for HLA-A24 in 11 families. Of the 11 families, 8 had 13 children who were negative for HBsAg. The 13 children (male/female $=6 / 7$; age range: $0-13$ years; mean age $\pm \mathrm{SD}: 5.4 \pm 3.4$ years) and their $8 \mathrm{HBV}$ carrier mothers (HBeAg positive, $\mathrm{n}=2$; antiHBe positive, $\mathrm{n}=6$, age range: $22-43$ years; mean age \pm SD: $31.3 \pm 7.6$ years) were enrolled in this study (Figure $1)$. During the follow-up period, blood samples were collected from all patients.

\section{Monoclonal antibodies and synthetic peptides}

Anti-HLA-A23, 24 monoclonal antibodies (mAbs) were purchased from One Lambda (Canoga Park, CA, USA). Goat anti-mouse immunoglobulin (IgG)-FITC Abs were purchased from Immunotech (Marseille, France). The HLA-A*2402 restricted HBV-specific CTL epitope core 117-125 (EYLVSFGVW) and HLA-A*2402-restricted HBV-specific CTL epitope Pol 756-764 (KYTSFPWLL) were previously identified [13]. These peptides were purchased from Nippi Research Institute of Biomatrix 


$$
\begin{array}{cc}
\text { Women who were positive for HBsAg } & \mathrm{n}=51 \\
\text { Women who were mothers } & \mathrm{n}=40 \\
\text { Mothers who were positive for } & \mathrm{n}=28 \\
\text { HLA-A24 } & \\
\downarrow & \mathrm{n}=11 \\
\text { Mothers whose children were } & \\
\text { positive for HLA-A24 } &
\end{array}
$$

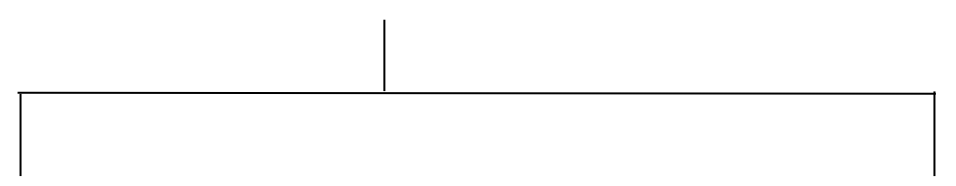

Both mothers and children were positive for HBsAg and HLA-A24

$$
\downarrow
$$

3 families

(3 mothers, 3 children)
Both mothers and children were positive for HLA-A24, but children were negative for HBsAg<smiles>C=[V]</smiles>

8 families

( 8 mothers, 13 children)

Figure 1 Subject enrollment.

(Tokyo, Japan). Peptide purity was determined by mass spectrometry and high-pressure liquid chromatography.

\section{HLA typing}

Detection of HLA-A24 was performed by flow cytometry using the HLA-A23, 24 mAbs as we described previously [14]. Because it is well established that HLA-A23 antigen is very rarely detected in Japanese populations $[15,16]$, the HLA-A23, 24-positive subjects were considered to be positive for HLA-A24. In brief, $200 \mu \mathrm{L}$ of EDTA or heparinized whole blood was stained with HLA-A23, $24 \mathrm{mAb}$ for 20 minutes at $4^{\circ} \mathrm{C}$. Whole blood stained with antiHLA-A23, $24 \mathrm{mAb}$ was washed with PBS. After incubation for 20 minutes at $4^{\circ} \mathrm{C}$ with FITC-labeled mouse IgG, the blood was washed again with PBS and lysed using FACS lysis solution (Becton Dickinson Sciences, San Jose, CA, USA). Samples were analyzed with a FACS Calibur machine (BD Bioscience, Becton Dickinson) using CellQuest software (BD Bioscience), after compensation was checked using freshly stained peripheral blood mononuclear cells (PBMCs).

\section{Pentamer assay}

PBMCs were isolated from heparinized venous blood by density gradient sedimentation using Ficoll-Hypaque (Lymphoprep; Axis Shield, Oslo, Norway). PBMCs were stained with R-phycoerythrin (PE)-labeled Pro5 MHC Pentamer HLA-A*2402/EYLVSFGVW and HLAA*2402/KYTSFPWLL (Proimmune, Oxford, UK) according to the manufacturer's instructions. In brief, $10 \mu \mathrm{L}$ of labeled Pentamer was added to a million PBMCs and mixed by pipetting. Samples were incubated at room temperature for 10 minutes, shielded from the light. Cells were washed with $2 \mathrm{~mL}$ of PBS, and then $1 \mu \mathrm{L}$ of antiCD8 FITC was added to the samples, which were then mixed by pipetting. The samples were incubated at $4^{\circ} \mathrm{C}$ for 20 minutes, shielded from the light, and then the cells were washed twice with PBS. Cells were stored in Cell Fix buffer (Becton Dickinson Immunocytometry Systems) at $4^{\circ} \mathrm{C}$ until analysis. Samples were analyzed with a FACS Calibur using CellQuest software, after compensation was checked using freshly stained PBMCs. On the basis of a previous study, $0.04 \%$ of total CD8-positive cells were 
considered to show non-specific binding in HBV infection [17].

\section{ELISPOT assay}

PBMCs were isolated from heparinized venous blood by density gradient sedimentation using Ficoll-Hypaque (Lymphoprep; Axis Shield, Oslo Norway). Fresh PBMCs were plated in 96-well polyvinylidene plates (Milipore, Bedford, MA, USA) that had been precoated with $0.5 \mu \mathrm{g} /$ $\mathrm{ml}$ anti-IFN- $\gamma$-mAb (Mabtech, Stockholm, Sweden). The peptides were added in a volume of $10 \mathrm{ul}$, and then PBMCs were added at 50,000-100,000 cells/well in a volume of $190 \mu \mathrm{l}$. The final concentration of core 117-125 (EYLVSFGVW) and pol 756-764 (KYTSFPWLL) was 5 $\mu \mathrm{M}$. The plates were incubated overnight at $37^{\circ} \mathrm{C}$ in $5 \%$ $\mathrm{CO}_{2}$ atmosphere and washed in PBS before the addition of the second biotinylated anti-IFN- $\gamma-\mathrm{mAb}$ (Mabtech) at $0.5 \mu \mathrm{g} / \mathrm{ml}$, followed by incubation at room temperature for $100 \mathrm{~min}$. After the plates were washed, streptavidinconjugated alkaline phosphatase (Mabtech) was added at room temperature, and the samples sat for 40 minutes. Individual cytokine-producing cells were detected as dark spots after a 20-minute reaction with 5-bromo-4chloro-3-indolyl phosphate and nitro blue tetrazolium using an alkaline phosphatase-conjugated substrate (BioRad Laboratories, Hercules, CA, USA). The number of specific $T$ cells was calculated by subtracting the negative control values and expressed as the number of spot-forming units per $10^{6}$ PBMCs. Wells were considered to exhibit a significant HBV-specific T-cell response if they had values of least twice as great as the background value and the number of spots was more than 50 .

\section{Real-time PCR assay}

To evaluate the relation between $\mathrm{HBV}$-specific T-cell responses and viremia, we examined whether $\mathrm{HBV}$ viremia was present in HBsAg-negative children. Real-time PCR is a sensitive method for detecting HBV DNA. We used the QIAamp UltraSens Virus DNA kit (QIAGEN, Valencia, CA, USA) to extract virus DNA according to the manufacturer's instructions. To enhance the detection, HBV DNA was extracted from $1 \mathrm{~mL}$ of serum and extracted DNA was concentrated. The extracted DNA was dissolved in $60 \mu \mathrm{L}$ of elution buffer, and $10 \mu \mathrm{L}$ of this solution was used for real-time PCR. Quantification of HBV DNA levels was performed using the genotypeindependent real-time PCR method described previously [18]. In brief, PCR was performed on a $50-\mu \mathrm{L}$ reaction mixture containing $25 \mu \mathrm{L}$ TaqMan Universal PCR master mix (Applied Biosystems, Foster City, CA, USA) with 0.2 $\mathrm{mM}$ primers, $0.1 \mathrm{mM}$ probes, and $10 \mu \mathrm{L}$ extracted DNA. The PCR program consisted of an initial pre-cycle incubation at $50^{\circ} \mathrm{C}$ for $2 \mathrm{~min}$ and $95^{\circ} \mathrm{C}$ for $10 \mathrm{~min}$, followed by 55 cycles of $95^{\circ} \mathrm{C}$ for $15 \mathrm{~s}$ and $60^{\circ} \mathrm{C}$ for $1 \mathrm{~min}$. The PCR assay was performed in a MX3000P machine (Stratagene), and the results were analyzed with MxPro software (version 3.0). This assay has a quantitative detection limit of 80 copies $/ \mathrm{mL}$. Therefore, this in-house PCR was as sensitive as commercially available real-time PCR such as the COBAS TaqMan HBV test (Roche).

\section{Statistical analysis}

The Chi-square test and Fisher's exact tests were used to compare frequencies. Results are presented as the mean \pm SD. Means were compared using Student's $t$-test or the Mann Whitney test. A $P$-value of .05 or less was considered to indicate statistical significance.

\section{Results}

\section{Characteristics of children and HBV carrier mothers}

To evaluate the immunity in children with successful immunoprophylactic treatment, we classified the children into two groups according to their HBsAg status. One group was the children who received immunoprophylactic treatment (HBIG combined with a 3-dose series hepatitis $B$ vaccine) after birth and remained negative for HBsAg (13 children from 8 families) (Table 1). The other group was the children who were positive for HBsAg (3 children from 3 families) (Table 2). Of the $3 \mathrm{HBsAg-posi-}$ tive children, one $(\mathrm{C} 10)$ did not receive immunoprophylactic treatment and became an HBV carrier. Despite immunoprophylactic treatment, the remaining two children in this group also became HBV carriers.

Characteristics of HBsAg-negative children and their mothers are shown in Table 1. Among the parents of children with successful immunoprophylactic treatment, 2 mothers were positive for $\mathrm{HBeAg}$ and the remaining 6 were negative for $\mathrm{HBeAg}$. The levels of serum alanine aminotransferase (ALT) (normal range: <35 IU/L) were slightly elevated in one mother (M5). On the other hand, the levels of serum ALT were normal in all children with successful immunoprophylactic treatment. Although 10 $\mathrm{mIU} / \mathrm{mL}$ or more was considered a protective level of serum anti-HBs, the level of serum anti-HBs was less than $10 \mathrm{mIU} / \mathrm{mL}$ in 4 children (C6a, C6b, C6c, and C7a). Antibodies to hepatitis B core (anti-HBc) are considered to be a marker of present or past infection. Two children (C3b and C8) were positive for anti-HBc. Because one child was a six-month-old baby, it was thought that his maternal anti-HBc could cross the placenta at birth.

Table 2 shows the characteristics of HBsAg-positive children and mothers. All of the children and mothers were positive for $\mathrm{HBeAg}$. The levels of serum ALT were normal in all of these children and mothers.

\section{ELISPOT assays}

We evaluated the function of $\mathrm{HBV}$-specific T-cells in HBsAg-negative children (those who had received suc- 
Table 1: Patient characteristics, IFN- $\gamma$ enzyme-linked immunosorbent spot, and serum HBV DNA levels of children with successful prophylactic treatment and their mothers.

\begin{tabular}{|c|c|c|c|c|c|c|c|c|c|}
\hline Patient ID* & $\begin{array}{c}\text { Age } \\
\text { (years) }\end{array}$ & Gender & $\begin{array}{l}\text { Levels of serum } \\
\text { hepatitis B } \\
\text { surface } \\
\text { antibodies } \\
\text { (mIU/mL) }\end{array}$ & $\begin{array}{c}\text { Hepatitis B e } \\
\text { antigen status }\end{array}$ & $\begin{array}{l}\text { Hepatitis B core } \\
\text { antibody status }\end{array}$ & $\begin{array}{l}\text { Levels of serum } \\
\text { ALT (IU/L) }\end{array}$ & $\begin{array}{l}\text { t core } 117-125 \\
\text { (spots/106 } \\
\text { PBMCs) }\end{array}$ & $\begin{array}{c}\text { pol 756-764 } \\
\text { (spots/106 } \\
\text { PBMCs) }\end{array}$ & $\begin{array}{c}\text { Levels of serum } \\
\text { hepatitis B virus } \\
\text { DNA } \\
\text { (copies } / \mathrm{mL} \text { ) }\end{array}$ \\
\hline M1 & 22 & & & Pos & Pos & 18 & 14.1 & 17.6 & $>10^{8.8}$ \\
\hline $\mathrm{C} 1$ & 2 & Female & 84.7 & & $\mathrm{Neg}$ & 16 & 0 & 5.0 & 100 \\
\hline M2 & 28 & & & Neg & Pos & 13 & 0 & 0 & $10^{4.0}$ \\
\hline $\mathrm{C} 2$ & 2 & Male & 40.6 & & $\mathrm{Neg}$ & 17 & 0 & 8.9 & 80 \\
\hline M3 & 43 & & & Neg & Pos & 10 & 4.5 & 0.9 & $10^{3.2}$ \\
\hline C3a & 11 & Female & 16.2 & & $\mathrm{Neg}$ & 8 & 0 & 6.5 & $\mathrm{Neg}$ \\
\hline $\mathrm{C} 3 \mathrm{~b}$ & 6 & Male & 172.1 & & Pos & 17 & 0 & 0 & $\mathrm{Neg}$ \\
\hline M4 & 32 & & & Neg & Pos & 11 & 30.8 & 47.3 & $10^{3.1}$ \\
\hline $\mathrm{C} 4$ & 6 & Male & 28.2 & & $\mathrm{Neg}$ & 15 & 13.9 & 94.4 & $\mathrm{Neg}$ \\
\hline M5 & 34 & & & Neg & Pos & 37 & 0 & 0 & $10^{3.0}$ \\
\hline C5a & 8 & Female & 118.9 & & $\mathrm{Neg}$ & 20 & 12.5 & 0 & $\mathrm{Neg}$ \\
\hline $\mathrm{C} 5 \mathrm{~b}$ & 6 & Female & 63.4 & & Neg & 13 & 68.0 & 114.3 & 80 \\
\hline M6 & 32 & & & Neg & Pos & 17 & 48.2 & 8.2 & $10^{3.7}$ \\
\hline C6a & 6 & Female & 6.3 & & $\mathrm{Neg}$ & 11 & 0 & 0 & Neg \\
\hline $\mathrm{C} 6 \mathrm{~b}$ & 4 & Female & $<5$ & & $\mathrm{Neg}$ & 12 & 40.0 & 0 & Neg \\
\hline $\mathrm{C} 6 \mathrm{c}$ & 2 & Male & $<5$ & & $\mathrm{Neg}$ & 11 & 2.9 & 29.4 & $\mathrm{Neg}$ \\
\hline M7 & 40 & & & Pos & Pos & 14 & 9.8 & 18.5 & $10^{8.1}$ \\
\hline $\mathrm{C} 7 \mathrm{a}$ & 13 & Male & $<5$ & & Neg & 18 & 0 & 0 & Neg \\
\hline $\mathrm{C} 7 \mathrm{~b}$ & 4 & Female & 34.2 & & Neg & 11 & 0 & 0 & $\mathrm{Neg}$ \\
\hline M8 & 22 & & & Neg & Pos & 15 & 0 & 0 & $10^{4.3}$ \\
\hline C8 & 0 & Male & 252.9 & & Pos & 17 & 29.1 & 0 & 80 \\
\hline
\end{tabular}

${ }^{*} \mathrm{M}$ and $\mathrm{C}$ indicate mother and child, respectively. Number indicates family ID. $†$ More than 50 spots $/ 10^{6}$ PBMCs were defined as a significant HBV-specific T-cell response. PBMCs, peripheral blood mononuclear cells. Pos, positive Neg, negative 
Table 2: Patient characteristics, IFN-ye nzyme-linked immunosorbent spot, and serum HBV DNA levels of hepatitis B surface antigen-positive children and their mothers.

\begin{tabular}{|c|c|c|c|c|c|c|c|}
\hline Patient ID* & $\begin{array}{c}\text { Age } \\
\text { (years) }\end{array}$ & Gender & $\begin{array}{l}\text { Levels of } \\
\text { serum ALT } \\
\text { (IU/L) }\end{array}$ & $\begin{array}{c}\text { Hepatitis B e } \\
\text { antigen } \\
\text { status }\end{array}$ & $\begin{array}{l}\text { + core 117-125 } \\
\text { (Spots/106 } \\
\text { PBMCs) }\end{array}$ & $\begin{array}{c}\text { pol 756-764 } \\
\text { (Spots/106 } \\
\text { PBMCs) }\end{array}$ & $\begin{array}{c}\text { Levels of } \\
\text { serum } \\
\text { hepatitis B } \\
\text { virus DNA } \\
\text { (copies } / \mathrm{mL} \text { ) }\end{array}$ \\
\hline M9 & 33 & & 18 & Pos & 12.6 & 53.9 & $>10^{8.8}$ \\
\hline $\mathrm{C} 9$ & 3 & Male & 33 & Pos & 12.8 & 5.7 & $10^{8.2}$ \\
\hline M10 & 47 & & 21 & Pos & 12.8 & 30.8 & 108.3 \\
\hline $\mathrm{C} 10$ & 22 & Female & 30 & Pos & 20.7 & 26.2 & $10^{8.6}$ \\
\hline M11 & 32 & & 17 & Pos & 22.5 & 48.4 & $10^{8.6}$ \\
\hline $\mathrm{C} 11$ & 4 & Female & 16 & Pos & 7.0 & 5.3 & $10^{8.7}$ \\
\hline
\end{tabular}

${ }^{*} \mathrm{M}$ and $\mathrm{C}$ indicate mother and child, respectively. Number indicates family ID. $†$ More than $50 \mathrm{spots} / 10^{6} \mathrm{PBMCs}$ were defined as a significant HBV-specific T-cell response. PBMCs, peripheral blood mononuclear cells. Pos, positive Neg, negative

cessful prophylactic treatment for mother-to-child transmission), HBsAg-positive children, and HBsAg-positive carrier mothers. IFN $\gamma$-ELISPOT assays were performed in both children and mothers. The results of ELISPOT assays in the group of HBsAg-negative children $(n=13)$ / HBsAg-positive mothers $(n=8)$ and HBsAg-positive children $(\mathrm{n}=3) / \mathrm{HBsAg}$-positive mothers $(\mathrm{n}=3)$ are shown in Tables 1 and 2, respectively. Surprisingly, a significant $\mathrm{HBV}$-specific $\mathrm{T}$-cell response (> 50 spots $/ 10^{6}$ PBMCs) was detectable in 2 of $13 \mathrm{HBs} A g-$ negative children (C4: pol 756-764; C5b: core 117-125, pol 756-764). However, anti-HBc antibodies were not detectable in the 2 children who showed significant HBV-specific T-cell responses.

No significant HBV-specific T-cell response was detected in the mothers of HBsAg-negative children. Likewise, none of the HBsAg-positive children had a significant response (Table 2), but one HBV carrier mother showed a significant response (M9; pol 756-764) (Table 2 ). Although there was no significant difference in the frequency of $\mathrm{HBV}$-specific $\mathrm{T}$-cell response to the two HBV-derived peptides between HBsAg-negative children and HBsAg-positive children (Table 3), these findings suggested that HBsAg-negative children who received prophylactic treatment have a potential to produce HBV-specific T-cell responses.

\section{HBV pentamer analysis}

HBV-specific CTLs play a crucial role in both virus clearance and the pathogenesis of hepatic cell injury. In particular, CTLs show a stronger response in cases of acute infection than in patients with chronic infection. MHC Class I peptide complexes (pentamers) can detect circulating HBV-specific CD8+ T cells. We performed pen- tamer staining to detect $\mathrm{HBV}$-specific CD8+ T cells in HBsAg-negative children $(n=10)$ and their mothers $(n=$ 5) (Table 4). None of the HBsAg-negative children showed a high frequency of pentamer-positive cells (Pentamer/CD8, core 117-125: $0.003 \pm 0.005 \%$, pol 756-764: $0.002 \pm 0.002 \%)$. Similarly, HBsAg carrier mothers did not show a high frequency of HBV-specific CD8+ T cells (Pentamer/CD8, core 117-125: 0.004 \pm 0.005\%, pol 756764: $0.001 \pm 0.002 \%)$. Because there was no study participant who showed more than $0.04 \%$ in frequency of $\mathrm{HBV}$ specific CD8+ T cells in this study, neither the HBsAgnegative children nor their mothers were classified as showing a positive response in this study. However, we did not have any positive controls. Therefore, further studies are required to interpret these results appropriately.

\section{Serum HBV DNA, serum HBsAb, and HBeAg status of mothers}

The levels of serum HBV DNA are shown in Table 1. Of the $13 \mathrm{HBsAg-negative} \mathrm{children,} 4$ (31\%) were positive for serum HBV DNA. However, the levels of serum HBV DNA were between 100 and 80 copies $/ \mathrm{mL}$. All of the children with $\mathrm{HBV}$ viremia were positive for anti-HBs. Although all of the $13 \mathrm{HBsAg-negative} \mathrm{children} \mathrm{received}$ prophylactic treatment, anti-HBs were not detectable in 3 of these children (23\%). One of the children with viremia (C1) was born to an HBeAg-positive mother, and the remaining 3 children with viremia $(\mathrm{C} 2, \mathrm{C} 5 \mathrm{~b}$, and $\mathrm{C} 8)$ were born to $\mathrm{HBeAg}$-negative mothers. Of 2 children who showed a significant response to $\mathrm{HBV}$ peptides in ELISPOT assay, one child ( $\mathrm{C} 5 \mathrm{~b}$ ) was positive for serum HBV DNA. Therefore, there was no association between 
Table 3: The frequency of children positive for IFN- $\gamma$ enzyme-linked immunosorbent spot assay HLA-A24 hepatitis B virusspecific cytotoxic T-cell epitope.

\begin{tabular}{|c|c|c|c|c|c|}
\hline & \multicolumn{5}{|c|}{ HLA-A24 hepatitis B virus-specific cytotoxic T-cell epitope } \\
\hline & $\begin{array}{l}\text { core } 117-125 \\
\text { No. of children } \\
\text { (\%) }\end{array}$ & & $\begin{array}{c}\text { pol 756-764 } \\
\text { No. of children } \\
(\%)\end{array}$ & & \\
\hline \multirow{2}{*}{$\begin{array}{l}\text { Hepatitis } B \\
\text { surface antigen-positive } \\
\text { children } \\
n=3\end{array}$} & $0(0)$ & 1 & $0(0)$ & 1 & \\
\hline & & & & & $P=0.81$ \\
\hline $\begin{array}{l}\text { Hepatitis } B \\
\text { surface antigen-negative } \\
\text { children } \\
n=13\end{array}$ & $1(7.7)$ & / & $2(15.4)$ & / & \\
\hline
\end{tabular}

the detection of serum HBV DNA and HBV-specific Tcell responses.

\section{Discussion}

Newborns born to HBsAg-positive mothers are usually exposed to HBV around delivery, except those who contract intra-uterine infection. The administration of HBIG containing neutralizing antibodies can prevent newborns from HBV infection for a few months after birth. Active hepatitis $B$ vaccine following HBIG administration induces active immunity and stimulates the production of sustained neutralizing antibodies against HBV in newborns. However, the overall immune response induced by both HBIG and hepatitis B vaccine in the prevention of mother-to-child transmission remains unclear. Although a small proportion of newborns treated with HBIG combined with hepatitis $\mathrm{B}$ vaccine become positive for $\mathrm{HBV}$ DNA from cord blood or peripheral blood transiently at or after birth, they eventually show no viremia $[9,10,19]$. In contrast, a proportion of newborns receiving HBIG combined with hepatitis vaccine become positive for anti-HBs, but HBV viremia persists after birth [10]. These observations suggest that newborns can be suffering from
HBV viremia transiently or for several years after birth, despite having received immunoprophylactic treatment. Our goal was to assess the association between T-cell responses and viremia in children after successful prophylactic treatment.

HBV viremia stimulates host cellular immunity, and CTLs can be involved in viral control $[11,17]$. The induction of HBV-core or polymerase-specific CTL indicates that HBV infects host cells and that HBV proteins presented on the surface of the host cells are recognized as targets by the host. In this study, 2 (15\%) of 13 children who were negative for HBsAg showed significant responses in IFN- $\gamma$ ELISPOT against HBV peptides. Because HBV-specific peptides were derived for core and polymerase protein in this study, these findings suggested that HBV-specific T-cells were primed due not to hepatitis $B$ vaccine but to the infection with HBV. In addition, one of the 2 children in whom HBV-specific T-cell responses were detectable was positive for serum $\mathrm{HBV}$ DNA. Although the levels of serum HBV DNA were low, viremia persisted despite $\mathrm{HBV}$-specific T-cells and antiHBs remaining detectable. These findings were similar to those in patients who suffered from acute HBV infection

Table 4: Pentamer assay in the hepatitis B virus carrier mothers and hepatitis B surface antigen-negative children after successful prophylactic treatment of mother-to-child transmission. 
[20,21]. In acute HBV infection, clinical recovery does not imply the complete clearance of serum or intrahepatic HBV DNA. The authors of previous studies reported that $\mathrm{HBV}$ viremia persisted and anti-viral T-cell responses were detectable for several years after resolution of acute hepatitis B [20-22]. The levels of serum HBV DNA are usually low after acute hepatitis B.

In animal models of acute hepatitis $\mathrm{B}$, functional T-cell responses were generated after infection using high doses of inoculated virus [23]. The results of one previous study suggested that exposure to a low viral load allows persistent viremia without priming functional T-cells [24]. Similarly, detection of functional T-cells might be closely related to the load of $\mathrm{HBV}$ to which children are exposed before, during, and after prophylactic treatment. However, the mothers of the 2 children in whom HBV-specific T-cells were detected were negative for HBeAg. Because HBeAg-negative mothers usually have a low viral load (Table 1), viral exposure alone might not explain the induction of HBV-specific T-cells in children. Some studies suggested that $\mathrm{HBeAg}$ might induce $\mathrm{T}$ cell tolerance in vertical transmission [25]. Therefore, viral genome mutations such as precore mutants, which are unable to secrete $\mathrm{HBeAg}$, could be associated with the outcome of mother-to-child transmission [26]. In C4, ELISPOT showed a positive result for polymerase protein but not core protein. This finding was consistent with that of a previous study, in which some patients showed positive results for both peptides and others showed positive results for only one peptide in acute HBV infection [17]. Although CTL responses are restricted with the HLA type, CTL responses to viral epitopes were different in each individual.

Various studies have been performed using PCR to evaluate the efficacy of immunization against $\mathrm{HBV}$ in infants born to HBV carrier mothers $[9,10]$. In a previous study, 2 of 29 (7\%) children who received HBIG and hepatitis $\mathrm{B}$ vaccine and became negative for $\mathrm{HBsAg}$ and positive for anti-HBs were positive for serum HBV DNA [9]. Of the 2 children, one was free of HBV viremia 2 years later. The other child became positive for HBsAg and negative for anti-HBs later, because the mutation in the " $a$ " determinant of the $S$ region occured. In another study, serum HBV DNA was detected at 4-6 years after birth by PCR in 14 of 94 (14\%) children who received prophylactic treatment [10]. Of the 14 children, 7 were negative for HBsAg and positive for anti-HBs. Three of the 7 children showed a high viral load ( $>10^{5}$ copies $/ \mathrm{mL}$ ), and the remaining 4 children showed a low viral load $(<200$ copies/mL). In the present study, real-time PCR was adopted to detect serum HBV DNA, as real-time PCR can be more sensitive than conventional PCR. In addition, serum HBV DNA was quantified more accurately. Serum HBV DNA was detected in 4 of 13 (31\%) children in our study, but the levels of HBV DNA were between 100 and 80 copies $/ \mathrm{mL}$. The prevalence rate of HBV viremia in this study was higher than that in previous studies $[9,10]$. The difference in the prevalence was presumably caused by the difference in the detection limit of each PCR method. Anti-HBc were detected in one of the 4 children with viremia. However, the child was a 6-month-old boy. Probably, maternal anti-HBc were transferred to the child through the placenta at birth [27]. Of the 4 children with viremia, 3 were born to HBeAg-negative mothers. In general, babies born to HBeAg-negative mothers are unlikely to become HBV carriers, even if immunoprophylactic treatment is not given. We cannot answer the question why 3 of 4 children with viremia were born to HBeAgnegative mothers. In a future study, the prevalence of viremia in a large number of children who received successful prophylactic treatment should be assessed.

Although escape mutants have been associated with persistence of serum HBV DNA after acute hepatitis B, the appearance of an escape mutant is uncommon in acute hepatitis B. In a previous study, variants in the $S$ region were detected in 2 of 14 children who received prophylactic treatment [10]. However, the 2 children were positive for $\mathrm{HBsAg}$, negative for anti-HBs antibodies, and infected with a high viral load $\left(>10^{8}\right.$ copies $\left./ \mathrm{mL}\right)$. The previous study results suggested that the majority of patients with viremia were infected with wild-type HBV after prophylactic treatment. Although we did not sequence the $S$ region, the mechanism of persistent viremia in children after the appearance of anti-HBs antibody might be different from that in children infected with escape variants. The level of serum anti-HBs antibodies considered protective is $>10 \mathrm{mIU} / \mathrm{mL}$ [28]. In the present study, the level of serum anti-HBsAb was $<10 \mathrm{mIU} / \mathrm{mL}$ in 4 of the 13 children who were negative for $\mathrm{HBsAg}$ after prophylactic treatment. Although it is controversial whether booster vaccination is required to maintain adequate levels of anti-HBs antibodies [28-30], all of the 4 children were negative for serum HBV DNA. All of these children had levels of anti-HBs antibodies $>10 \mathrm{mIU} / \mathrm{mL}$ at 1 year after birth. However, the levels of anti-HBs antibodies decreased to $<10 \mathrm{mIU} / \mathrm{mL}$ over time. None of the 4 children showed a significant HBV-specific T-cell response. Further studies are needed to evaluate the role of HBV-specific T-cell responses in children who lose anti-HBs after prophylactic treatment.

The results of this study raise questions about the longterm clinical impact of a low-dose HBV infection in children. For instance, children with a low-dose infection could suffer from hepatocelluar carcinoma in the future. In addition, the new emerging biological therapies for immunomodulation, including tumor necrosis factor inhibitors and anti-B cell agents such as Rituximab, will induce reactivation of $\mathrm{HBV}$ with a potentially fatal out- 
come in adult patients with chronic HBV infection or occult HBV infection [31,32]. Because this study was cross-sectional, we could not answer these questions. Longitudinal studies in children receiving prophylactic treatment are necessary to properly assess these issues and answer these questions.

\section{Conclusion}

In conclusion, HBV core and polymerase-specific T-cell responses were detectable in children after the appearance of anti-HBs antibodies, although rarely. Moreover, a low-level viremia was observed in nearly 1 in 3 children. Although the presence of a low-level viremia was not related to HBV-specific T-cell responses, our study results showed that CTLs might play a role in the control of HBV infection in children born to HBsAg-positive mothers after immunoprophylactic treatment. Because the number of subjects in the present study was small, additional studies are required to evaluate virological and immunological issues, including the role of CTLs in children after immunoprophylactic treatment.

\section{Abbreviations}

Anti-HBe: antibodies to hepatitis B e antigen; Anti-HBs: antibodies to hepatitis B surface antigen; CTLs: cytotoxic T lymphocytes; ELISPOT: enzyme-linked immunosorbent spot; HBeAg: hepatitis B e antigen; HBIG: hepatitis B immunoglobulin; HBsAg: hepatitis B surface antigen; HBV: hepatitis B virus; $\mathrm{MHC}$ : major histocompatibility complex; PBMCs: peripheral blood mononuclear cells.

\section{Competing interests}

The authors declare that they have no competing interests.

\section{Authors' contributions}

HK and PK contributed to the design of this study and drafted this manuscript. $\mathrm{Al}, \mathrm{TS}, \mathrm{EH}, \mathrm{AT}$, and TF participated in data collection and critically revised the manuscript. All the authors concurred with the submission and will take the responsibility for the manuscript.

\section{Author Details}

1Department of Pediatrics, Yokohama Eastern Hospital, 3-6-1 Shimosueyoshi Tsurumi Yokohama, Kanagawa 230-0012, Japan, 2Department of Pediatrics, Sakura Medical Center, Toho University 564-1 Shimoshizu Sakura, Chiba 2858741, Japan and ${ }^{3}$ Nuffield Department of Medicine, Peter Medawar Building for Pathogen Research, University of Oxford, South Parks Road, Oxford, OX1 3SY, UK

Received: 1 January 2010 Accepted: 28 April 2010

Published: 28 April 2010

\section{References}

1. Beasley RP, Hwang LY, Lin CC, Chien CS: Hepatocellular carcinoma and hepatitis B virus. A prospective study of 22707 men in Taiwan. Lancet 1981, 2(8256):1129-33.

2. McMahon BJ, Alberts SR, Wainwright RB, Bulkow L, Lanier AP: Hepatitis Brelated sequelae. Prospective study in 1400 hepatitis $B$ surface antigen-positive Alaska native carriers. Arch Intern Med 1990, 150(5):1051-4.

3. Beasley RP, Trepo C, Stevens CE, Szmuness W: The e antigen and vertical transmission of hepatitis B surface antigen. Am J Epidemiol 1977, 105(2):94-8.

4. Slowik MK, Jhaveri R: Hepatitis $B$ and $C$ viruses in infants and young children. Semin Pediatr Infect Dis 2005, 16(4):296-305.

5. Lee C, Gong Y, Brok J, Boxall EH, Gluud C: Effect of hepatitis B immunisation in newborn infants of mothers positive for hepatitis B surface antigen: systematic review and meta-analysis. BMJ 2006, 332(7537):328-36

6. Wong VC, Ip HM, Reesink HW, Lelie PN, Reerink-Brongers EE, Yeung CY, et al:: Prevention of the $\mathrm{HBsAg}$ carrier state in newborn infants of mothers who are chronic carriers of $\mathrm{HBsAg}$ and $\mathrm{HBeAg}$ by administration of hepatitis- $B$ vaccine and hepatitis-B immunoglobulin. Double-blind randomised placebo-controlled study. Lancet 1984, 1(8383):921-6.

7. Stevens CE, Taylor PE, Tong MJ, Toy PT, Vyas GN, Nair PV, et al:: Yeastrecombinant hepatitis $B$ vaccine. Efficacy with hepatitis $B$ immune globulin in prevention of perinatal hepatitis $B$ virus transmission. JAMA 1987, 257(19):2612-6.

8. Andre FE, Zuckerman AJ: Review: protective efficacy of hepatitis B vaccines in neonates. J Med Virol 1994, 44(2):144-51.

9. Matsumoto T, Nakata K, Hamasaki K, Daikokoku M, Nakao K, Yamashita Y, et al: Efficacy of immunization of high-risk infants against hepatitis $B$ virus evaluated by polymerase chain reaction. J Med Virol 1997 53(3):255-60.

10. Kato H, Nakata K, Hamasaki K, Hida D, Ishikawa H, Aritomi T, et al:: Longterm efficacy of immunization against hepatitis $B$ virus in infants at high-risk analyzed by polymerase chain reaction. Vaccine 1999, 18(78):581-7.

11. Chisari FV, Ferrari C: Hepatitis B virus immunopathogenesis. Annu Rev Immunol 1995, 13:29-60

12. Ota MO, Vekemans J, Schlegel-Haueter SE, Fielding K, Whittle H, Lambert $\mathrm{PH}$, et al:: Hepatitis B immunisation induces higher antibody and memory Th2 responses in new-borns than in adults. Vaccine 2004, 22(3-4):511-9.

13. Sobao Y, Sugi K, Tomiyama H, Saito S, Fujiyama S, Morimoto M, et al:: Identification of hepatitis $B$ virus-specific CTL epitopes presented by HLA-A* the most common HLA class I allele in East Asia. J Hepatol 2402, 34(6):922-9.

14. Komatsu H, Inui A, Sogo T, Fujisawa T, Nagasaka H, Nonoyama S, et al:: Large scale analysis of pediatric antiviral CD8+ T cell populations reveals sustained, functional and mature responses. Immun Ageing 2006, 3:11.

15. Tanaka H, Akaza T, Juji T: Report of the Japanese Central Bone Marrow Data Center. Clin Transp/ 1996:139-44.

16. Tokunaga K, Ishikawa Y, Ogawa A, Wang H, Mitsunaga S, Moriyama S, et al:: Sequence-based association analysis of HLA class I and II alleles in Japanese supports conservation of common haplotypes. Immunogenetics 1997, 46(3):199-205.

17. Sobao Y, Tomiyama H, Sugi K, Tokunaga M, Ueno T, Saito S, et al.: The role of hepatitis B virus-specific memory CD8 T cells in the control of viral replication. J Hepatol 2002, 36(1):105-15.

18. Liu Y, Hussain M, Wong S, Fung SK, Yim HJ, Lok AS: A genotypeindependent real-time $P C R$ assay for quantification of hepatitis $B$ virus DNA. J Clin Microbiol 2007, 45(2):553-8.

19. Bai H, Zhang L, Ma L, Dou XG, Feng GH, Zhao GZ: Relationship of hepatitis $B$ virus infection of placental barrier and hepatitis $B$ virus intra-uterine transmission mechanism. World J Gastroenterol 2007, 13(26):3625-30.

20. Michalak TI, Pasquinelli C, Guilhot S, Chisari FV: Hepatitis B virus persistence after recovery from acute viral hepatiti s. J Clin Invest 1994, 93(1):230-9.

21. Penna A, Artini M, Cavalli A, Levrero M, Bertoletti A, Pilli M, et al: Longlasting memory $\mathrm{T}$ cell responses following self-limited acute hepatitis B. J Clin Invest 1996, 98(5):1185-94.

22. Yotsuyanagi $H$, Yasuda $K$, lino S, Moriya K, Shintani Y, Fujie H, et al:: Persistent viremia after recovery from self-limited acute hepatitis $B$. Hepatology 1998, 27(5):1377-82.

23. Michalak TI, Mulrooney PM, Coffin CS: Low doses of hepadnavirus induce infection of the lymphatic system that does not engage the liver. $J$ Virol 2004, 78(4):1730-8.

24. Zerbini A, Pilli M, Boni C, Fisicaro P, Penna A, Di Vincenzo P, et al: The characteristics of the cell-mediated immune response identify different profiles of occult hepatitis B virus infection. Gastroenterology 2008, 134(5):1470-81.

25. Milich $\mathrm{D}$, Liang TJ: Exploring the biological basis of hepatitis $B$ e antigen in hepatitis B virus infection. Hepatology 2003, 38(5):1075-86.

26. Terazawa S, Kojima M, Yamanaka T, Yotsumoto S, Okamoto H, Tsuda F, et al:: Hepatitis B virus mutants with precore-region defects in two babies 
with fulminant hepatitis and their mothers positive for antibody to hepatitis B e antigen. Pediatr Res 1991, 29(1):5-9.

27. Wang JS, Chen H, Zhu QR: Transformation of hepatitis B serologic markers in babies born to hepatitis $B$ surface antigen positive mothers. World J Gastroenterol 2005, 11(23):3582-5.

28. Zanetti AR, Mariano A, Romano L, D'Amelio R, Chironna M, Coppola RC, et al: Long-term immunogenicity of hepatitis $B$ vaccination and policy for booster: an Italian multicentre study. Lancet 2005, 366(9494):1379-84.

29. Kao JH, Chen DS: Hepatitis B vaccination: to boost or not to boost? Lancet 2005, 366(9494):1337-8.

30. Ward SM, Phalora P, Bradshaw D, Leyendeckers H, Klenerman P: Direct ex vivo evaluation of long-lived protective antiviral memory $B$ cell responses against hepatitis B virus. J Infect Dis 2008, 198(6):813-7.

31. Yeo W, Chan PK, Zhong S, Ho WM, Steinberg JL, Tam JS, et al:: Frequency of hepatitis $B$ virus reactivation in cancer patients undergoing cytotoxic chemotherapy: a prospective study of 626 patients with identification of risk factors. J Med Virol 2000, 62(3):299-307.

32. Hui CK, Cheung WW, Zhang HY, Au WY, Yueng YH, Leung AY, et al.: Kinetics and risk of de novo hepatitis B infection in HBsAg-negative patients undergoing cytotoxic chemotherapy. Gastroenterology 2006, 131(1):59-68

\section{Pre-publication history}

The pre-publication history for this paper can be accessed here: http://www.biomedcentral.com/1471-2334/10/103/prepub

\section{doi: 10.1186/1471-2334-10-103}

Cite this article as: Komatsu et al. Cellular immunity in children with successful immunoprophylactic treatment for mother-to-child transmission of hepatitis B virus BMC Infectious Diseases 2010, 10:103

Submit your next manuscript to BioMed Central and take full advantage of:

- Convenient online submission

- Thorough peer review

- No space constraints or color figure charges

- Immediate publication on acceptance

- Inclusion in PubMed, CAS, Scopus and Google Scholar

- Research which is freely available for redistribution

Submit your manuscript at www.biomedcentral.com/submit
C Biomed Central 